\title{
WHY DO NOT POLYPHENOLS OF RED WINE PROTECT AGAINST THE HARMFUL EFFECTS OF ALCOHOL IN ALCOHOLISM?
}

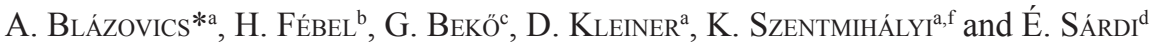 \\ ${ }^{a}$ Department of Pharmacognosy, Semmelweis University, H-1085 Budapest Üllöi út 26. Hungary \\ ${ }^{\mathrm{b}}$ National Agricultural Research \& Innovation Centre Research Institute for Animal Breeding, Nutrition \& Meat \\ Science Herceghalom, H-2053 Herceghalom, Gesztenyés út 1. Hungary \\ ${ }^{\mathrm{c}}$ Central Laboratory, Uzsoki Street Hospital, H-1145 Budapest, Uzsoki utca 29-41. Hungary \\ ${ }^{\mathrm{d} D e p a r t m e n t ~ o f ~ G e n e t i c s ~ a n d ~ P l a n t ~ B r e e d i n g, ~ F a c u l t y ~ o f ~ H o r t i c u l t u r a l ~ S c i e n c e, ~ S z e n t ~ I s t v a ́ n ~ U n i v e r s i t y, ~}$ \\ H-1118 Budapest, Ménesi út 44. Hungary;

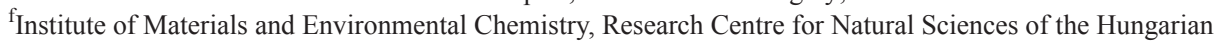 \\ Academy of Sciences, H-1117 Budapest, Magyar Tudósok Körutja 2. Hungary
}

(Received: 2 December 2018; accepted: 17 February 2019)

The effect of polyphenolic bioactive substances, especially resveratrol $\left(12.03 \mathrm{mg} \mathrm{l}^{-1}\right)$, of an often consumed Hungarian red wine was investigated in a short term rat experiment. Male young Wistar albino rats were treated with high volumes of red wine (matching one bottle of wine/day for a $85 \mathrm{~kg}$ man) $(\mathrm{N}=5)$ and another alcoholic drink of the same alcohol concentration ( $\mathrm{N}=5)$, corresponding to the circumstances of alcoholism, and 5 rats were in the control group. A total of 7 routine laboratory parameters were measured from the sera by kits.

The changes of redox homeostasis (H-donor activity, induced chemiluminescence, diene-conjugates, GSHPx) were studied in blood plasma and/or in liver homogenates by spectrophotometric and luminometric methods. Transmethylation property of the liver was measured by overpressured layer chromatography (OPLC) technique. It was proven with in vitro OPLC analytical study that resveratrol reacted with methyl groups, and resveratrol was demonstrated to influence transmethylation processes as well as redox homeostasis. Red wine compounds do not protect from the harmful effects of alcohol, and even by high doses of resveratrol, the liver further deteriorates and the negative effect of alcohol increases. It has been confirmed that high doses of resveratrol do not provide protection against liver damage in those suffering from alcoholism.

Keywords: resveratrol, alcohol, hepatotoxicity, transmethylation, redox homeostasis

\section{Abbreviations:}

ADH: alcohol dehydrogenase; ALDH: aldehyde dehydrogenase; ALP: alkaline phosphatase; ALT: alanine transaminase; AST: aspartate transaminase; CHOL: cholesterol; CREAT: creatinine; CYP: cytochrome P450 isoenzymes; DPPH: 2,2-diphenyl-1-picryl-hydrazyl radical; GSH: glutathione; GSHPx: glutahione peroxidase; HCHO: formaldehyde; HDON: H-donor activity; MALDI-MS: matrix-assisted laser desorption/ionization - mass spectrometry; OPLC: overpressured layer chromatography; RLU: relative light unit; ROS: reactive oxidative substances; UA: uric acid; TG: triglyceride

The number of alcoholics and people suffering from diseases related to alcohol consumption increases in the world (HERBERT et al., 2017) despite that several studies have drawn the conclusion that biologically active antioxidant polyphenolic compounds, in particular flavonoids and stilbenes, found in red wine, have favourable physiological effects. Especially

\footnotetext{
* To whom correspondence should be addressed.

Phone: +36 20825 0479; e-mail: blazovics.anna@pharma.semmelweis-univ.hu
} 
trans-resveratrol (resveratrol) reduces hazards of various cardiovascular diseases as well as cancer, diabetes, and so on (Szende et al., 2000; Bradamante et al., 2004; Chiva-Blanch et al., 2013; Moreno-Indias et al., 2016; OH \& SHAhidi, 2018).

Resveratrol shows several biological effects, and the compound appears to have multiple molecular targets. For example, it inhibits the activity of various CYP enzymes and their expression through various nuclear factors, induces or inhibits Phase II enzymes, furthermore enhances fibrosis in a continuous gastric infusion rat model of ethanol exposure. Along with alcohol consumption, enhanced autophagy has also been observed (Wu et al., 2012; McGiLL et al., 2015).

The in vivo antioxidant property of resveratrol is more likely to be attributable to its effect as a gene regulator. Resveratrol increases the expression of various antioxidant enzymes. Some of the gene-regulating effects of resveratrol are mediated by the histone/ protein deacetylase sirtuin-1 or by the nuclear factor-E2-related factor-2 (MCCuBREY et al., 2017; XiA et al., 2017).

At dosage of $0.02 \mathrm{mg} \mathrm{kg}^{-1}$, resveratrol promoted antioxidant defence by preventing total and reduced GSH depletion caused by ischemia-reperfusion in rat liver, however, at high dosage $\left(20 \mathrm{mg} \mathrm{kg}^{-1}\right)$, it became prooxidant with an aggravation of liver injury, marked by aminotransferase release and histological picture, and associated with a depletion of total/ reduced GSH levels and a decrease of antioxidant enzyme activities (HASSAN-KHABBAR et al., 2008).

An 8-week resveratrol administration (daily $3000 \mathrm{mg}$ ) has not benefited overweight/ obese patients with non-alcoholic fatty liver disease in an Australian clinical study. ALT and AST increased significantly, but resveratrol was well-tolerated (CHACHAY et al., 2014).

Ethanol is converted into acetaldehyde through three major metabolic pathways. In the cytosol ALD, in the microsomes inducible CYP2E1, and in the peroxisomes catalase are involved in the transformation (LIEBER, 1997). During alcohol metabolism, primary and secondary ROS can be observed. Acetaldehyde accelerates GSH depletion and ROS mediated toxicity (WORRAL et al., 1993). CYP2EI is a major ROS generator, because ethanol reacts with $\mathrm{H}_{2} \mathrm{O}_{2}$, formed at detoxification, meanwhile forming a 1-hydroxyethyl free radical (DuPONT et al., 1998).

GSH, which can inhibit ROS reactions, is rapidly eliminated in alcoholism. This is due to the lack of sufficient methionine for the synthesis of cysteine, the main factor of GSH synthesis. Since the concentration of S-adenosylmethionine decreases in the cirrhotic liver considerably, the GSH regeneration slows down. In the absence of S-adenosylmethionine, many other vital metabolic pathways are also hindered. It is also proven that transfer of a methyl group happens via the formation of $\mathrm{HCHO}$ during the endogenous transmethylation processes. The abnormalities of the HCHO cycle may be potential risk factors (ТYIHÁK et al., 1998).

Resveratrol is a concentration-dependent $\mathrm{HCHO}$ capture molecule. In oxidizing environment, ROS can be formed in the reaction of resveratrol with HCHO. Quantum chemical calculations support the possibility of interaction between resveratrol and $\mathrm{HCHO}$ in biological systems, in which methoxy and formyl derivatives can be formed as presented in the study of MoLNÁR and co-workers (2008). TYIHÁK and co-workers (2011) analysed the reaction products of $\mathrm{HCHO}$ and resveratrol as well as $\mathrm{HCHO}$ and heart tissue by OPLC and MALDI-MS.

In this experiment, we were curious to know whether the polyphenol (1004 $\left.\mathrm{mg} \mathrm{l}^{-1}\right)$, flavonoid (quercetin $13.7 \mathrm{mg} \mathrm{l}^{-1}$, catechin $54.2 \mathrm{mg} \mathrm{l}^{-1}$, anthocyanins $73 \mathrm{mg} \mathrm{l}^{-1}$ ), and resveratrol 
rich $\left(12.03 \mathrm{mg} \mathrm{l}^{-1}\right)$ red wine (alcohol concentration: 10.5\%) consumption can modify the redox-balance involving GSHPx antioxidant enzyme activity and transmethylation processes.

\section{Materials and methods}

\subsection{Materials}

Egri cuvee red wine was purchased from Wine-cellars König (Hungary).

$\mathrm{HCHO}$, DPPH, methanol, resveratrol, luminol, $\mathrm{H}_{2} \mathrm{O}_{2}$, microperoxidase, and bovine serum albumin were obtained from Sigma (USA). Routine laboratory kits were Reanal kits. All other reagents were of analytical grade, purchased from Reanal (Budapest).

\subsection{Animal experiment}

Male Wistar rats of 150-200 g were involved in the experiment. The animals were divided into three groups. Each group contained 5 rats. All animals were kept on normal rat chow. The controls were given tap water to drink. Alcohol-water solution of $10.5 \mathrm{v} / \mathrm{v} \%$ or wine with the same alcohol concentration was added to the rats in alcohol treated groups. The rats were treated daily $8 \mathrm{ml} \mathrm{kg}^{-1}$ of body weight alcoholic solutions or wine for 10 days (which matches one bottle of wine/day for a $85 \mathrm{~kg}$ man). The animals were exsanguinated through the abdominal vein in deep pentobarbital narcosis $(35 \mathrm{mg} / \mathrm{bw} \mathrm{kg}$ i.p) on day 10 , and blood was collected. Liver, sera, and plasma were prepared for the measurements. Measurements with kits were carried out and chemiluminescence as well as diene conjugates were detected promptly and consecutively, and all samples were stored at $-20{ }^{\circ} \mathrm{C}$ for other measurements. Permission Number: 770/004/04.

\subsection{Methods}

Blood was collected into tubes containing citrate for the plasma and native tubes for the sera (Greiner), and was centrifuged immediately at $4{ }^{\circ} \mathrm{C}$ at 3000 r.p.m. for 10 min using standard method.

The liver was taken out, washed, and broken into small pieces, then washed with isotonic $\mathrm{KCl}$ solution. The bloodless liver pieces were homogenised with Potter-Elvehjem homogeniser at $0-4{ }^{\circ} \mathrm{C}$. The homogenates were standardised by protein content by the method of LOWRY and co-workers (1951) with bovine serum albumin.

AST, ALT, ALP, TG, CHOL, UA, and CREAT were carried out with Hitachi Modular and Advia 12 equipments using Reanal kits. HDON activity was determined by the method of HATANO and co-workers (1988). Chemiluminescense assay was adopted from BLÁzovics and SÁRDI (2018). Diene conjugates were determined after 20 hours at $\lambda_{232} \mathrm{~nm}$ according to AOAC method (1984). GSHPx antioxidant enzyme activity was measured by RANSEL RS505 Randox kit.

Dimedone is a $\mathrm{HCHO}$ capture molecule, therefore, quantification of formaldehyde is via formaldemethone. $\mathrm{HCHO}$, as its dimedone adduct formaldemethone, has been detected with a fast and accurate OPLC by the methods of SÁRDI and TYIHÁK (1998). Molar ratio: resveratrol 1, HCHO 5, dimedone solution 10 in methanol for 24 hours. The reaction mixture was used for chromatographic separations. The chromatographic separations were carried out on Silica gel $60 \mathrm{~F}_{254}$ precoated chromatoplates (Merck Co., Germany) using a chloroform-methylene 
chloride mixture $(35: 65, \mathrm{~V} / \mathrm{V})$ for formaldemethone determination. Calibration curves were made by means of authentic substances at $\lambda=265 \mathrm{~nm}$ for formaldemethone.

The liver samples were treated with dimedone solution $(0.05 \%$ dimedone in methanol) for 24 hours. This suspension was centrifuged at $1500 \mathrm{~g}$ for $10 \mathrm{~min}$ at $4{ }^{\circ} \mathrm{C}$. The clear supernatants were used for chromatographic separations. The chromatographic separations were the same as described before.

\subsection{Statistical analysis}

For comparison of the results, Student's $t$-test or Kruskal-Wallis test and ANOVA were done with Statistica 13 software. The significance level was determined at $\mathrm{P}<0.05$. Mean $\pm \mathrm{SD}$ and c.v. \% were calculated from the data.

\section{Results and discussion}

In rats that consumed red wine, significantly higher ALP and UA values were measured. There were no changes in lipids, TG, and CHOL concentrations or in the CREAT of sera (Table 1). Red wine significantly increased non-enzymatic antioxidant levels in the plasma, while GSHPx levels were significantly reduced in both alcohol treated groups compared to the controls. Alcohol reduced and red wine increased free radical levels (RLU) in plasma compared to the controls.

Table 1. Changes of routine laboratory parameters during alcohol and red wine treatments

\begin{tabular}{lccccccc}
\hline $\begin{array}{l}\text { Groups } \\
(\mathrm{mean} \pm \mathrm{SD})\end{array}$ & $\begin{array}{c}\mathrm{AST} \\
\left(\mathrm{U}^{-1}\right)\end{array}$ & $\begin{array}{c}\text { ALT } \\
\left(\mathrm{U} \mathrm{l}^{-1}\right)\end{array}$ & $\begin{array}{c}\text { ALP } \\
\left(\mathrm{U} \mathrm{l}^{-1}\right)\end{array}$ & $\begin{array}{c}\text { TG } \\
\left(\mathrm{mmol} \mathrm{l}^{-1}\right)\end{array}$ & $\begin{array}{c}\text { CHOL } \\
\left(\mathrm{mmol} \mathrm{l}^{-1}\right)\end{array}$ & $\begin{array}{c}\text { UA } \\
\left(\mu \mathrm{mol} \mathrm{l}^{-1}\right)\end{array}$ & $\begin{array}{c}\text { CREAT } \\
(\mu \mathrm{mol} \mathrm{l}\end{array}$ \\
\hline Control & 63.16 & $32.83^{\mathrm{a}}$ & $545^{\mathrm{a}}$ & 0.84 & 1.65 & $3.87^{\mathrm{a}}$ & 30.16 \\
$(\mathrm{~N}=5)$ & \pm 5.30 & \pm 3.76 & \pm 42 & \pm 0.40 & \pm 0.18 & \pm 2.16 & \pm 1.47 \\
Alcohol treated & 55.20 & $26.80^{\mathrm{b}}$ & $490^{\mathrm{b}}$ & 0.63 & 1.46 & $8.20^{\mathrm{b}}$ & 29.20 \\
$(\mathrm{~N}=5)$ & \pm 5.44 & \pm 3.27 & \pm 49 & \pm 0.20 & \pm 0.15 & \pm 2.58 & \pm 1.78 \\
Red wine treated & 56.20 & 30.60 & $560^{\mathrm{c}}$ & 0.70 & 1.50 & $12.00^{\mathrm{b}}$ & 27.60 \\
$(\mathrm{~N}=5)$ & \pm 7.98 & \pm 3.50 & \pm 70 & \pm 0.17 & \pm 0.33 & \pm 7.11 & \pm 1.81 \\
\hline
\end{tabular}

Significance $\mathrm{P}<0.05$ : a vs $\mathrm{b}, \mathrm{b}$ vs c

The transmethylation abilities of livers were different among the groups. In both treated groups, liver $\mathrm{HCHO}$ concentrations (in formaldemethone form) were significantly lowered compared to the control group. The strong ROS reactions (RLU) and the moderated activity of enzymatic defence led to formation of diene conjugates of lipids (Table 2), even though concentration of antioxidant molecules (HDON) in treated groups was high.

Figure 1 shows the changes in formaldemethone concentrations without and with resveratrol in an in vitro experiment. When the resveratrol-formaldehyde reaction product with dimedone in OPLC system was detected, the molar ratio was: resveratrol 1, HCHO 5, dimedon 10 . 
Table 2. Changes of antioxidant profile of plasma and liver homogenates during alcohol and red wine treatments

\begin{tabular}{|c|c|c|c|c|c|c|c|}
\hline $\begin{array}{l}\text { Groups } \\
(\text { mean } \pm \text { SD) }\end{array}$ & $\begin{array}{c}\text { Plasma } \\
\text { HDON } \\
\left(\mathrm{mmol} \mathrm{l}^{-1}\right) \\
\end{array}$ & $\begin{array}{c}\text { Plasma } \\
\text { GSHPx } \\
\left(\mathrm{U}^{-1}\right)\end{array}$ & $\begin{array}{l}\text { Plasma } \\
\text { (RLU) }\end{array}$ & $\begin{array}{l}\text { Diene- con- } \\
\text { jugates } \\
\left(\text { Abs. }_{233} / \mathrm{ml}\right)\end{array}$ & $\begin{array}{c}\text { Liver } \\
\text { HDON } \\
\left(\mathrm{mmol} \mathrm{l}^{-1}\right) \\
\end{array}$ & $\begin{array}{l}\text { Liver } \\
\text { (RLU) }\end{array}$ & $\begin{array}{l}\mathrm{HCHO} \\
\left(\mu \mathrm{g} \mathrm{g}^{-1}\right)\end{array}$ \\
\hline $\begin{array}{l}\text { Control } \\
(\mathrm{N}=5)\end{array}$ & $\begin{array}{l}1.067^{\mathrm{a}} \\
\pm 0.21\end{array}$ & $\begin{array}{l}3955^{\mathrm{a}} \\
\pm 500\end{array}$ & $\begin{array}{l}1.274 \times 10^{6 \mathrm{a}} \\
\text { c.v. }<0.5 \%\end{array}$ & $\begin{array}{l}0.191^{\mathrm{a}} \\
\pm 0.057\end{array}$ & $\begin{array}{l}46.84 \\
\pm 8.91\end{array}$ & $\begin{array}{l}1.983 \times 10^{6 \mathrm{a}} \\
\text { c.v. }<0.5 \%\end{array}$ & $\begin{array}{l}7.29^{\mathrm{a}} \\
\pm 1.29\end{array}$ \\
\hline $\begin{array}{l}\text { Alcohol } \\
\text { treated } \\
(\mathrm{N}=5)\end{array}$ & $\begin{array}{l}1.004 \\
\pm 0.23\end{array}$ & $\begin{array}{l}4263^{\mathrm{b}} \\
\pm 476\end{array}$ & $\begin{array}{l}7.26 \times 10^{5 b} \\
\text { c.v. }<0.5 \%\end{array}$ & $\begin{array}{c}0.239 \\
\pm 0.053\end{array}$ & $\begin{array}{l}48.55 \\
\pm 7.80\end{array}$ & $\begin{array}{c}2.388 \times 10^{6 b} \\
\text { c.v. }<0.5 \%\end{array}$ & $\begin{array}{l}5.72^{\mathrm{b}} \\
\pm 1.04\end{array}$ \\
\hline $\begin{array}{l}\text { Red wine } \\
\text { treated } \\
(\mathrm{N}=5)\end{array}$ & $\begin{array}{c}1.215^{\mathrm{b}, \mathrm{c}} \\
\pm 0.11\end{array}$ & $\begin{array}{l}3585^{\mathrm{c}} \\
\pm 458\end{array}$ & $\begin{array}{c}1.811 \times 10^{6 \mathrm{~b}, \mathrm{c}} \\
\text { c.v. }<0.5 \%\end{array}$ & $\begin{array}{l}0.308^{b} \\
\pm 0.053\end{array}$ & $\begin{array}{l}52.21 \\
\pm 5.07\end{array}$ & $\begin{array}{c}3.082 \times 10^{6 b, c} \\
\text { c.v. }<0.5 \%\end{array}$ & $\begin{array}{l}5.22^{\mathrm{b}} \\
\pm 0.41\end{array}$ \\
\hline
\end{tabular}

Significance $\mathrm{P}<0.05$ : a vs $\mathrm{b}, \mathrm{b}$ vs c

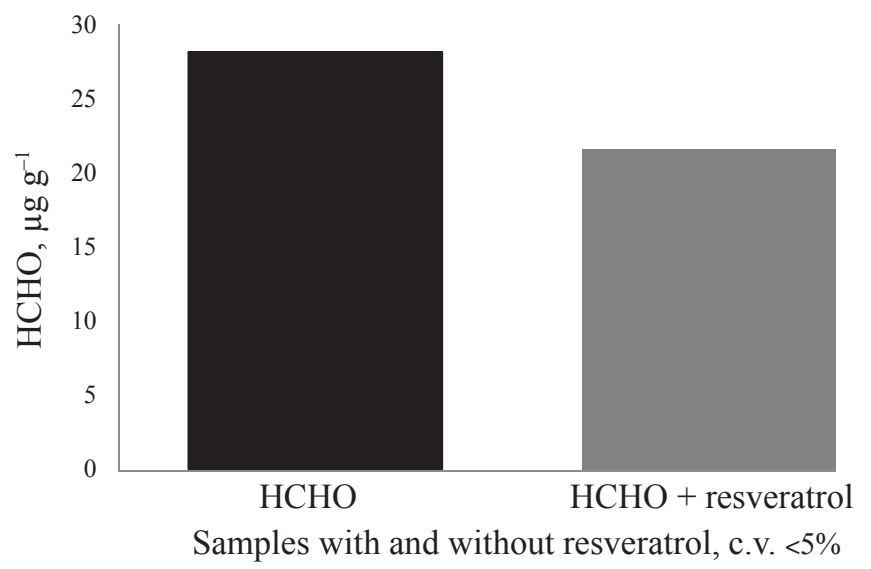

Fig. 1. Detection of resveratrol-formaldehyde reaction product with dimedone system (Molar ration: resveratrol 1: $\mathrm{HCHO}$ 5: dimedon 10)

The HCHO concentration in formaldemethone without resveratrol was $28.2 \mu \mathrm{g} \mathrm{g}^{-1} \pm \mathrm{c} . \mathrm{v}$. $5 \%$ and with resveratrol was $21.6 \mu \mathrm{g} \mathrm{g}^{-1} \pm$ c.v. $5 \%$.

Since it is known that the concentration of S-adenosylmethionine, the main methylation agent in the body, is reduced in alcoholism, the question is, whether the bioactive components (flavonoids and resveratrol) of red wine can contribute to a moderation in alcoholic liver diseases? According to the literature, the answer is linked to resveratrol (TYıнÁk et al., 1998; 2011). Egri cuvée contains a high concentration of resveratrol, almost 1.5-3 times higher than the commercially available red wines (VRHOVSEK et al., 1995; SouTO et al., 2001).

It was verified in an in vitro dimedone reaction system that resveratrol can react with bound HCHO, also confirmed by MoLnÁR and co-workers (2008).

The equivalent alcohol content of red wine and alcoholic drink did not damage the liver functions significantly in this short term, 10-day-long experiment, which is clearly apparent from the routine laboratory results, but the redox parameters indicate that red wine surprisingly favours lipid peroxidation processes. 
Among plasma redox parameters, H-donor activity indicated that red wine polyphenols could be absorbed in rats. Non-specific antioxidant protection diminished the activity of GSHPx significantly. The plasma inducible ROS level increased due to the consumption of red wine. Interestingly, the alcohol diminished its level, which could be due to the fact that the antioxidant compounds of the rat chow could be absorbed better by the alcohol, while the excess antioxidant compounds of wine could already modify the redox equilibrium negatively.

The effectiveness of red wine-derived antioxidants could be detected by the moderately higher H-donor activity in the liver. At the same time, lipid peroxidation processes were intensified. Higher diene conjugation concentration and significant inducible chemiluminescence intensity indicated ROS formation in the livers of both treated groups. Meanwhile, a significant decrease was observed in methylation capacity in both treated groups.

To prove that resveratrol was the cause of moderated transmethylation ability during red wine treatment, an in vitro experiment was conducted.

The primary cause was found to be the decreased concentration of methyl groups accompanying the metabolism of alcohol, and the reaction of resveratrol with HCHO was the next. The HCHO molecule is in connection with the redox homeostasis, playing an important role with ROS in the biological system. According to our in vitro and in vivo data, it is assumed that resveratrol $\mathrm{HCHO}$ reaction might affect the methylation level, causing changes in enzyme activity of glutathione peroxidase via lower glutathione concentration through the formaldehyde cycle (TYıнÁK et al., 1998).

\section{Conclusions}

Damage caused by the alcohol content of the wines cannot be avoided by other bioactive compounds of the wines in case of alcoholism. Our results confirm that resveratrol is a Janus faced bioactive molecule.

This research was supported by NKFIH-FK128793 project and the Higher Education Institutional Excellence Program (20430-3/2018/FEKUTSTRAT) awarded by the Ministry of Human Capacities within the framework of plant breeding and plant protection researches of Szent István University. The authors are grateful to the Ph.D. program of the Semmelweis University. The authors wish to thank Andrea Balázs Ph.D. for her wine analytical works, and Mrs. Edina Pintér and Mrs. Sarolta Bárkovits for their excellent technical assistance.

\section{References}

AOAC (1984): Official Methods of Analysis. 14 ${ }^{\text {th }}$ ed. Arlington, USA, Method 8054B.

Blázovics, A. \& SÁrdi, É. (2018): Methodological repertoire development to study the effect of dietary supplementation in cancer therapy. Microchem. J., 136, 121-127.

Bradamante, S., Barenghi, L. \& Villa, A. (2004): Cardiovascular protective effects of resveratrol. Cardiovasc. Drug Rev., 22, 169-188.

Chachay, V.S., MacDonald, G.A., Martin, J.H., Whitehead, J.P., O’Moore-Sullivan, T.M., ... \& Hickman, I.J. (2014): Resveratrol does not benefit patients with non-alcoholic fatty liver disease. Clin. Gastroenterol. H., 12, 2092-2103.

Chiva-Blanch, G., Urpi-Sarda, M., Ros, E., Valderas-Martinez, P., Casas. R., .... \& Estruch, R. (2013): Effects of red wine polyphenols and alcohol on glucose metabolism and the lipid profile: a randomized clinical trial. Clin Nutr., 32, 200-206. 
Dupont, I., Lucas, D., Clot, P. Ménez, C. \& Albano, E. (1998): Cytochrome P4502E1 inducibility and hydroxyethyl radical formation among alcoholics. J. Hepatol., 28, 564-571.

Hassan-Khabbar, S., Cottart, C.H., Wendum, D., Vibert, F., Clot, J.P., .. \& Nivet-Antoine, V. (2008): Postischemic treatment by trans-resveratrol in rat liver ischemia-reperfusion: A possible strategy in liver surgery Liver Transplant., 14, 451-459.

Hatano, T., Kagawa, H., Yasuhara, T. \& Okuda, T. (1988): Two new flavonoids and other constituents in licorice root: their relative astringency and radical scavenging effects. Chem. Pharm. Bull., 36, 2090-2097.

Herbert, A., Gilbert, R., Cottrell, D. \& Li, L. (2017): Causes of death up to 10 years after admissions to hospitals for self-inflicted, drug-related or alcohol-related, or violent injury during adolescence: a retrospective, nationwide, cohort study. Lancet, 390(10094), 577-587.

Lieber, C.S. (1997): Ethanol metabolism, cirrhosis, and alcoholism. Clin. Chim. Acta., 257, 59-84.

Lowry, O.H., Rosebrough, N.J., Farr, A.L. \& Randall, R.J. (1951): Protein measurement with Folin phenol reagent. J. Biol. Chem., 93, 265-275.

McCubrey, A., Lertpiriyapong, K., Steelman, L.S., Abrams, S.L., Yang, L.V., .. \& \& Cervello, M. (2017): Effects of resveratrol, curcumin, berberine and other nutraceuticals on aging, cancer development, cancer stem cells and microRNAs. Aging US, 9, 1477-1536.

McGill, M.R., Du, K., Weemhoff, J.L. \& JaeschKe, H. (2015): Critical review of resveratrol in xenobiotic-induced hepatotoxicity. Food Chem. Toxicol., 86, 309-318.

Molnár, V., Billes, F., TYinÁK, E. \& Miкosch, H. (2008): Theoretical study on the vibrational spectra of methoxyand formyl-dihydroxy-trans-stilbenes and their hydrolytic equilibria. Spectrochim. Acta A, 69, 542-558.

Moreno-Indias, I.,SÁnchez-Alcoholado, L., Pérez-Martínez, P., Andrés-Lacueva, C. \& Cardona F. (2016): Red wine polyphenols modulate fecal microbiota and reduce markers of the metabolic syndrome in obese patients. Food Funct., 7, 1775-1787.

OH, W.Y. \& Shahidi, F. (2018): Antioxidant activity of resveratrol ester derivatives in food and biological model systems. Food Chem., 261, 267-273.

SÁRDI, É. \& TYıнÁK, E. (1998): Relationship between dimedone concentration and formaldehyde captured in plant tissues. Acta Biol. Hung., 49, 291-301.

Souto, A.A., Carneiro, M.C., Seferin, M., Senna, M.J.H., Conz, A. \& Gobbi, K. (2001): Determination of transresveratrol concentrations in Brazilian red wines by HPLC. J. Food Compos. Anal., 14, 441-445.

Szende, B., TyinÁk, E. \& KirÁly-Véghely, Z. (2000): Dose-dependent effect of resveratrol on proliferation and apoptosis in endothelial and tumor cell cultures. Exp. Mol. Med., 32, 88-92.

Tyinák, E., Albert, L., Németh, Zs.I., Kátay, Gy., Király-Véghely, Z. \& Szende, B. (1998): Formaldehyde cycle and the natural formaldehyde generators and capturers. Acta Biol. Hung., 49, 225-238.

TyinÁk, E., KirÁly-VÉghely, Zs. \& Móricz, Á.M. (2011): Multiple beneficial effects of resveratrol and their chemical basis. Nat. Prod. Commun., 6, 631-638.

VRhovsek, U., Eder, R. \& Wendelin, S. (1995): The occurrence of trans-resveratrol in Slovenian red and white wines. Acta Alimentaria, 24, 203-212.

Worrall, S., de Jersey, J., Nicholls, R. \& Wilce, P.A. (1993): Acetaldehyde/protein interactions: are they involved in the pathogenesis of alcoholic liver disease? Digest. Dis., 11, 265-277.

Wu, D., Wang, X., Zhou, R., YAng, L. \& Cederbaum, A.I. (2012): Alcohol steatosis and cytotoxicity: the role of cytochrome P4502E1 and autophagy, Free Radical Bio. Med., 53, 1346-1357.

Xia, N., Daiber, A., Förstermann, U. \& Li, H. (2017): Antioxidant effects of resveratrol in the cardiovascular system. Brit. J. Pharmacol., 174, 1633-1646.

Open Acces statement. This is an open-access article distributed under the terms of the Creative Commons Attribution 4.0 International License (https://creativecommons.org/licenses/by/4.0/), which permits unrestricted use, distribution, and reproduction in any medium, provided the original author and source are credited, a link to the $\mathrm{CC}$ License is provided, and changes - if any - are indicated. (SID_1) 